\title{
Cannabidiol Modulates Fear Memory Formation Through Interactions with Serotonergic Transmission in the Mesolimbic System
}

\author{
Christopher Norris, ${ }^{1,2}$, Michael Loureiro',2, Cecilia Kramar ${ }^{1,2}$, Jordan Zunder ${ }^{1,2}$, Justine Renard ${ }^{1,2}$, \\ Walter Rushlow ${ }^{1,2,3}$ and Steven R Laviolette*, I,2,3,4 \\ 'Addiction Research Group, Schulich School of Medicine and Dentistry, University of Western Ontario, London, ON, Canada; ${ }^{2}$ Department of \\ Anatomy and Cell Biology, Schulich School of Medicine and Dentistry, University of Western Ontario, London, ON, Canada; ${ }^{3}$ Department of \\ Psychiatry, Schulich School of Medicine and Dentistry, University of Western Ontario, London, ON, Canada; ${ }^{4}$ Department of Psychology, Schulich \\ School of Medicine and Dentistry, University of Western Ontario, London, ON, Canada
}

\begin{abstract}
Emerging evidence suggests that the largest phytochemical component of cannabis, cannabidiol (CBD), may possess pharmacotherapeutic properties in the treatment of neuropsychiatric disorders. CBD has been reported to functionally interact with both the mesolimbic dopamine (DA) and serotonergic (5-HT) receptor systems. However, the underlying mechanisms by which CBD may modulate emotional processing are not currently understood. Using a combination of in vivo electrophysiological recording and fear conditioning in rats, the present study aimed to characterize the behavioral, neuroanatomical, and pharmacological effects of CBD within the mesolimbic pathway, and its possible functional interactions with $5-\mathrm{HT}$ and DAergic transmission. Using targeted microinfusions of CBD into the shell region of the mesolimbic nucleus accumbens (NASh), we report that intra-NASh CBD potently blocks the formation of conditioned freezing behaviors. These effects were challenged with DAergic, cannabinoid CBI receptor, and serotonergic (5-HT IA) transmission blockade, but only 5-HTIA blockade restored associative conditioned freezing behaviors. In vivo intra-ventral tegmental area (VTA) electrophysiological recordings revealed that behaviorally effective doses of intra-NASh CBD elicited a predominant decrease in spontaneous DAergic neuronal frequency and bursting activity. These neuronal effects were reversed by simultaneous blockade of 5-HT IA receptor transmission. Finally, using a functional contralateral disconnection procedure, we demonstrated that the ability of intra-NASh CBD to block the formation of conditioned freezing behaviors was dependent on intra-VTA GABAergic transmission substrates. Our findings demonstrate a novel NAc $\rightarrow$ VTA circuit responsible for the behavioral and neuronal effects of CBD within the mesolimbic system via functional interactions with serotonergic 5- $\mathrm{HT}$ IA receptor signaling.

Neuropsychopharmacology (2016) 4I, 2839-2850; doi:I 0.I038/npp.2016.93; published online 6 July 2016
\end{abstract}

\section{INTRODUCTION}

There is ongoing debate regarding the potential therapeutic potential of cannabis-derived phytochemicals in the treatment of neuropsychiatric conditions. Central to this debate is emerging evidence demonstrating that separate phytochemical constituents of cannabis may possess differential pharmacological and psychotropic effects. Although $\Delta-9$ tetrahydrocannabinol (THC) is considered the primary psychoactive component of marijuana, cannabis contains over 70 distinct compounds (ElSohly and Slade, 2005; Radwan et al, 2009). Of these, cannabidiol (CBD), which is

*Correspondence: Dr SR Laviolette, Department of Anatomy and Cell Biology, Schulich School of Medicine and Dentistry, University of Western Ontario, 468 Medical Science Building, London, ON, Canada N6A 5Cl, Tel: + I 519661 21।I, ext 80302, Fax: + 5196613936 , E-mail: steven.laviolette@schulich.uwo.ca

Received I2 February 20 I6; revised 6 June 20 I 6; accepted 8 June 20 I6; accepted article preview online 14 June 2016 considered non-psychoactive, is the most abundant. In contrast to THC, CBD is an agonist at the $5 \mathrm{HT}_{1 \mathrm{~A}}$ receptor (Russo et al, 2005) and decreases cellular reuptake and hydrolysis of the endocannabinoid anandamide, potentiating its central effects (Bisogno et al, 2001).

In terms of psychotropic profiles, THC is associated with transient and long-term psychotomimetic effects (Bhattacharyya et al, 2012; Murray et al, 2007), whereas clinical and preclinical research has shown that CBD can produce antipsychotic and anxiolytic effects (Crippa et al, 2011; Campos et al, 2012; Fogaca et al, 2014; Zuardi et al, 2006, 2012; Mechoulam et al, 2007; Leweke et al, 2012; Renard et al, 2016a; Schubart et al, 2014; Gomes et al, 2015). In addition, $\mathrm{CBD}$ may modulate emotional memory processing and decrease symptoms associated with emotional memory disorders such as post-traumatic stress disorder (PTSD; Blessing et al, 2015,Betthauser et al, 2015).

While the precise neuroanatomical regions responsible for CBD's actions are not known, considerable evidence implicates the nucleus accumbens (NAc) as an important site 
for CBD's modulatory effects on various cognitive and behavioral phenomena (Guimarães et al, 2004; Bhattacharyya et al, 2009; Valvassori et al, 2011; Mijangos-Moreno et al, 2014; Pedrazzi et al, 2015). For example, CBD attenuates THCinduced dysregulation of the ventral striatum during verbal recall tasks (Bhattacharyya et al, 2009) and increases c-fos and adenosine levels in rodent NAc (Guimarães et al, 2004; Mijangos-Moreno et al, 2014). In addition, CBD blocks amphetamine-induced oxidative stress in the NAc (Valvassori et $a l, 2011)$ and intra-NAc CBD attenuates amphetamineinduced deficits in prepulse inhibition (Pedrazzi et al, 2015; Renard et al, 2016b). Nevertheless, the precise functional and pharmacological mechanisms by which $\mathrm{CBD}$ may produce these effects in the mesolimbic system are not currently understood.

In the present study, we investigated the potential effects of CBD on fear-related memory formation and how CBD may modulate neuronal activity states within the mesolimbic circuitry. Using a combination of behavioral conditioning and in vivo neuronal electrophysiological recordings, we report that intra-NAc $\mathrm{CBD}$ dose-dependently blocks the formation of associative fear memories measured by conditioned freezing behaviors and blunts the activity of DAergic neurons in the ventral tegmental area (VTA). Furthermore, these effects were dependent on intra-shell region of the mesolimbic nucleus accumbens (NASh) serotonergic $\left(5-\mathrm{HT}_{1 \mathrm{~A}}\right)$ receptor transmission and functional interactions between the NASh and GABAergic transmission in the VTA.

\section{MATERIALS AND METHODS}

\section{Rats and Surgery}

Male Sprague-Dawley rats (300-350 g; Charles River, Senneville, QC, Canada) were anesthetized with ketamine (80 mg/ml)-xylazine (6 mg/kg; intraperitoneally) and placed in a stereotaxic apparatus. An incision was made to expose the skull, and stainless steel guide cannulae (22 G; Plastics1) were implanted into the NASh using the following stereotaxic coordinates $\left(12^{\circ}\right.$ angle, $\mathrm{mm}$ from bregma): anteroposterior $(\mathrm{AP})+1.8$, lateral $(\mathrm{LAT}) \pm 2.6$, and ventral $(\mathrm{V})-7.4$ from the dural surface and the following coordinates for the VTA ( $10^{\circ}$ angle, $\mathrm{mm}$ from bregma): AP -5.0 , LAT \pm 2.6 , and $\mathrm{V}-8.0$ from the dural surface. Coordinates were based on the Atlas of Paxinos and Watson (2005). Rats in the NASh-VTA disconnection groups received single unilateral NASh cannulation and contralateral VTA cannulation. All experimental procedures were performed in accordance with the regulations of the Canadian Council on animal care (CCAC) and the University of Western Ontario.

\section{Drug Administration}

The broad-spectrum DA receptor antagonist, $\alpha$-flupenthixol ( $\alpha$-flu; Tocris), the $\mathrm{GABA}_{\mathrm{A}}$ antagonist, bicuculline methiodide (Tocris), and the $\mathrm{GABA}_{\mathrm{B}}$ antagonist, hydroxysaclofen (Tocris), were dissolved in physiological saline ( $\mathrm{pH}$ adjusted to 7.4). The 5- $\mathrm{HT}_{1 \mathrm{~A}}$ receptor antagonist, NAD 299 hydrochloride (Tocris), CBD (Tocris), and CB1R antagonist, SR141716A (rimonabant, RIM), were first dissolved in dimethyl sulfoxide (DMSO) and then diluted in PBS for a final 1\% DMSO in PBS vehicle (VEH) solution. Microinfusions were performed over $1 \mathrm{~min}$ through a Hamilton microsyringe. To ensure adequate diffusion, injector cannulae were left in place for an additional $1 \mathrm{~min}$.

\section{Olfactory Fear Conditioning}

We used a previously described olfactory fear conditioning paradigm to measure fear memory formation (Lauzon et al, 2009; Draycott et al, 2014). Two distinct environments were used. Environment A was a 30 in $\times 30$ in Plexiglass box with black spots on a white background and environment $\mathrm{B}$ was a 30 in $\times 30$ in Plexiglass box with black and white stripes. The designated shock environment had a metallic grid shock floor, while the designated test environment had a smooth gray Plexiglas floor. The environments were assigned as 'shock' and 'test' in a counterbalanced manner such that all rats with 'shock' environment A were tested in environment $\mathrm{B}$ and all rats with 'shock' environment B were tested in environment A. On day 1 (habituation), rats were given sham microinfusions into the NASh and habituated to both conditioning environments for $30 \mathrm{~min}$. Footshocks were delivered at an intensity of $0.8 \mathrm{~mA}$ (for $1 \mathrm{~s}$ ), which we have previously reported to produce highly robust conditioned freezing behaviors (Lauzon et al, 2009; Draycott et al, 2014). On day 2 (conditioning phase), rats were returned to the room and, immediately before being placed in previously assigned 'shock' environment, rats received intra-NASh microinfusions of $\operatorname{CBD}(1,10$, and $100 \mathrm{ng} /$ $0.5 \mu \mathrm{l})$; the DA antagonist $\alpha$-flu $(100 \mathrm{ng}-1.0 \mu \mathrm{g} / 0.5 \mu \mathrm{l})$, alone or in combination with $\mathrm{CBD}$; the $5-\mathrm{HT}_{1 \mathrm{~A}}$ antagonist NAD 299 hydrochloride $(10-100 \mathrm{ng} / 0.5 \mu \mathrm{l})$, alone or in combination with CBD (100 ng). Two odors were delivered during conditioning, almond and peppermint. One odor was presented with a footshock $(\mathrm{CS}+)$ and the other was presented in the absence of a footshock (CS - ). After $1 \mathrm{~min}$ in the 'shock' environment, the CS - odor was presented for $20 \mathrm{~s}$. After $2 \mathrm{~min}$, the CS+ odor was presented for $19 \mathrm{~s}$ followed by a $1 \mathrm{~s}$ footshock delivered through the shock floor. This cycle was repeated five times. On day 3 (test phase), rats were placed in the previously assigned test environment. They were given $1 \mathrm{~min}$ to explore the environment before odor presentations began, during which time baseline levels of freezing behavior were recorded. Both $\mathrm{CS}+$ and CS - odors were presented in a fully counterbalanced order for $5 \mathrm{~min}$ and amounts of time rat's spent freezing (lack of movement except for respiration) was recorded and analyzed with ANY-MAZE video software for offline analysis.

\section{Footshock Sensitivity Tests}

To ensure that intra-NASh infusions of CBD, NAD 299, or $\alpha$-flu were having no effect on baseline sensitivity to footshock stimulation during fear memory acquisition, separate control groups received either bilateral intra-NASh microinfusions of $\mathrm{VEH}, \mathrm{CBD}(100 \mathrm{ng} / 0.5 \mu \mathrm{l})$, NAD 299 (500 ng/0.5 $\mu \mathrm{l})$, or $\alpha$-flu $(1000 \mathrm{ng} / 0.5 \mu \mathrm{l})$ alone immediately before a sensitivity testing phase wherein rats received five test shock administrations $(0.8 \mathrm{~mA}, 1 \mathrm{~s}$, in the absence of any cue delivery), once per minute over a total of $5 \mathrm{~min}$. During 
this time, levels of freezing behavior, total distance traveled, and the number of jumping events were recorded with ANYMAZE video software and analyzed offline.

\section{In Vivo Electrophysiological Recordings}

In vivo single-cell extracellular VTA recordings were performed as described previously (Loureiro et al, 2015; Tan et al, 2009). Briefly, rats were anesthetized with urethane $(1.4 \mathrm{~g} / \mathrm{kg}$, intraperitoneally) and placed in a stereotaxic frame with body temperature maintained at $37^{\circ} \mathrm{C}$. A scalp incision was made and holes were drilled in the skull above the NASh and VTA. For intra-NASh microinfusion of CBD (100 ng/0.5 $\mu \mathrm{l}$ ), a $1 \mu \mathrm{l}$ Hamilton syringe was slowly lowered at the same coordinates used for behavioral studies. For intraVTA extracellular recording, glass microelectrodes (with an average impedance of 6-8 M $\Omega$ ) filled with a $2 \%$ Pontamine Sky Blue solution were lowered using a hydraulic micropositioner (Kopf 640) at the following flat skull stereotaxic coordinates (in mm from bregma): AP - 5.3, LAT \pm 0.7 from midline, ventral $(\mathrm{V})-7.0$ to -8.5 from the dural surface. Extracellular signals were amplified using a MultiClamp 700B amplifier (Molecular Devices) and recorded through a Digidata 1440A acquisition system (Molecular Devices) using the pClamp 10 software. Extracellular recordings were filtered at $1 \mathrm{kHz}$ and sampled at $5 \mathrm{kHz}$. VTA DA neurons were identified according to well-established electrophysiological features (Ungless et al, 2004; Jalabert et al, 2011): (1) a relatively long action potential width ( $>2.5 \mathrm{~ms}$ ); (2) a slow spontaneous firing rate $(2-5 \mathrm{~Hz})$; (3) a biphasic waveform consisting of a notch on the rising phase followed by a delayed after potential; and (4) a single irregular or bursting firing pattern. VTA GABA interneurons were also characterized based on previously reported criteria: (1) a narrow action potential width ( $<1 \mathrm{~ms}$ ); (2) relatively fast firing rates (typically between 10 and $20 \mathrm{~Hz}$ ); and (3) the absence of bursting activity. Neurons that failed to clearly meet the aforementioned criteria for VTA DA or VTA non-DA electrophysiological neuronal properties were excluded from postexperimental analyses. Recordings analyses were accomplished using the Clampfit 10 software. Response patterns of isolated VTA neurons following intra-NASh CBD microinfusions were determined by comparing neuronal frequency rates between the 5 min preinfusion $v s$ postinfusion epochs. Classification of drug-infusion effects used a criterion of a $\geqslant 10 \%$ increase in firing frequency postinfusion to be classified as an increase; $a \leqslant 10 \%$ decrease to be classified as a decrease. Neurons showing firing frequency parameters within these cutoff points were classified as 'no change'. For VTA DA neurons, we also analyzed the bursting rate and number of spikes within each burst. The onset of a burst was defined as the occurrence of two consecutive spikes with an interspike interval of $<80 \mathrm{~ms}$. For histological analysis of extracellular VTA neuronal recording sites, recording electrode positions were marked with iontophoretic deposit of Pontamine Sky Blue dye $(-20 \mu \mathrm{A}$, continuous current for 12-15 min). Rats were then perfused transcardially with isotonic saline followed by $10 \%$ formalin. Brains were removed and stored in a $25 \%$ sucrose-formalin solution before sectioning $(40 \mu \mathrm{m}$ sections) on a freezing cryostat. Following this, sections were stained with neutral red and infusion and/or neuronal recording sites were confirmed with light microscopy.

\section{NASh-VTA Functional Disconnection Studies}

Previous research has established the functional connectivity between the NAc and the VTA, whereby GABAergic projections from the NAc are capable of modulating VTA DAergic and non-DAergic neuronal activity states (Nauta et al, 1978; Kalivas et al, 1993). To determine if the behavioral effects of intra-NASh CBD were due to modulatory influences from the NASh $\rightarrow$ VTA, we performed a functional disconnection procedure, similar to one described previously (Rosen et al, 2015). In this procedure, to disconnect the effects of intra-NASh CBD from intra-VTA GABAergic transmission, experimental groups had microinjector cannulae placed unilaterally in the NASh of one hemisphere, and the VTA of the contralateral hemisphere. Group 1 received intra-VTA VEH followed by intra-NASh VEH. Group 2 received intra-VTA VEH followed by intraNASh CBD $(100 \mathrm{ng} / 0.5 \mu \mathrm{l})$. Group 3 received intra-VTA microinfusion of the $\mathrm{GABA}_{\mathrm{A}}$ receptor antagonist bicuculline methiodide $(50 \mathrm{ng} / 0.5 \mu \mathrm{l})$ with the selective $\mathrm{GABA}_{\mathrm{B}}$ antagonist hydroxysaclofen $(100 \mathrm{ng} / 0.5 \mu \mathrm{l})$, followed by intra-NASh CBD $(100 \mathrm{ng} / 0.5 \mu \mathrm{l})$. Group 4 received the intra-VTA bicuculline/hydroxysaclofen mixture followed by intraNASh VEH. All groups received the intra-VTA treatment 2 min before intra-NASh treatments. The hemispheres for unilateral/contralateral cannulations were counter-balanced within groups to control for laterality. All groups were then subjected to the same olfactory fear conditioning paradigm described above.

\section{Data Analysis}

Data were analyzed with one- or two-way ANOVA, followed by post hoc paired-samples $t$-tests or Newman-Keuls tests, where appropriate.

\section{RESULTS}

\section{Histological Analyses}

Histological analysis revealed injector placements localized within the anatomical boundaries of the shell subdivision of the NAc or VTA, according to Paxinos and Watson (2005). Figure 1a presents a microphotograph displaying a typical injector placement within the NASh, relative to the 'core' subdivision. Figure 1b displays a schematic illustration showing representative intra-NASh cannulae placements along the rostral-caudal axis of the NAc. Black circles represent $\mathrm{VEH}$ control rats receiving for shows a microphotograph displaying typical bilateral intra-NASh injector placements.

\section{Intra-NASh CBD Dose-Dependently Blocks the Formation of Associative Fear Memory}

We first examined the potential effects of intra-NASh $\mathrm{CBD}$ on the acquisition of associative fear memory (see Materials and Methods). Using a wide dose range of bilateral intra-NASh CBD $(1 \mathrm{ng}-100 \mathrm{ng} / 0.5 \mu \mathrm{l})$, we challenged the 

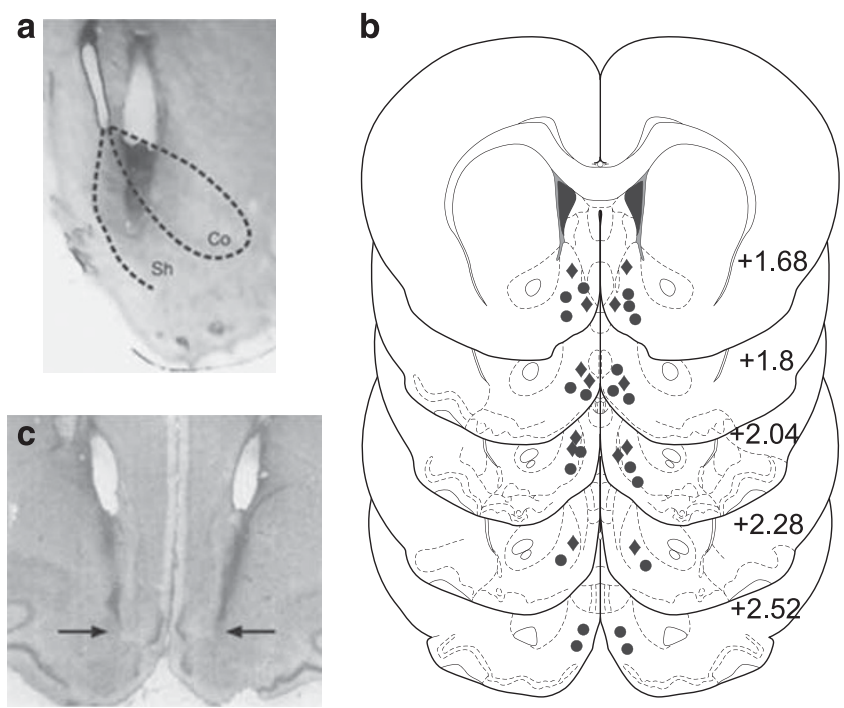

Figure I Histological analysis of intra-shell region of the mesolimbic nucleus accumbens (NASh) microinjection sites. (a) Microphotograph of a representative injector placement within the shell subdivision of the nucleus accumbens (NAc). (b) Schematic representation of select intra-NASh injector locations. $=100 \mathrm{ng}$ cannabidiol (CBD) groups, $\bullet=100 \mathrm{ng}$ CBD+100 ng NAD299 group. (c) Microphotograph of representative intra-NASh bilateral cannulae placements (black arrows).

acquisition of fear memory by administering CBD immediately before the fear conditioning session. ANOVA comparing percentages of time spent freezing during testing revealed a significant main effect of group $\left(\mathrm{F}_{(7,287)}=5.75, p=0.0001\right)$. Post hoc analyses revealed that whereas rats treated with intra-NASh VEH $(n=6)$ and rats treated with a lower dose of $\mathrm{CBD}(1 \mathrm{ng} / 0.5 \mu \mathrm{l}, n=7)$ spent significantly greater amounts of time freezing in the presence of the CS+ ( $p$ 's $<0.05,0.01$, respectively), rats receiving either $10 \mathrm{ng}(n=8)$ or $100 \mathrm{ng}(n=6)$ of intra-NASh CBD showed no associative freezing in response to $\mathrm{CS}-v s \mathrm{CS}+$ cue presentations ( $p$ 's $>0.05$; Figure 2a). In addition, associative freezing in response to $\mathrm{CS}+$ presentations were significantly lower relative to $\mathrm{VEH}$ controls for both the $10 \mathrm{ng}$ and $100 \mathrm{ng}$ CBD groups ( $p$ 's $<0.01$; Figure $2 \mathrm{a}$ ). Thus, bilateral intraNASh CBD dose-dependently blocks the formation of conditioned fear memories measured with conditioned freezing behaviors. Accordingly, we selected the highest behaviorally effective dose of $100 \mathrm{ng} / 0.5 \mu \mathrm{l}$ as the challenge dose for subsequent behavioral and electrophysiological experiments.

\section{Intra-NASh CBD Modulates Fear Memory Formation Through a $5-\mathrm{HT} 1_{\mathrm{A}}$-Dependent Mechanism Memory}

Given previous evidence demonstrating that $\mathrm{CBD}$ produces its pharmacological effects via the $5-\mathrm{HT}_{\mathrm{A}}$ receptor (Russo et al, 2005), we next challenged the effects of intra-NASh CBD (100 ng) with coadministration of the selective $5-\mathrm{HT}_{1 \mathrm{~A}}$ receptor antagonist, NAD 299 (10-100 ng/0.5 $\mu \mathrm{l})$. ANOVA comparing percentages of time spent freezing during testing revealed a significant main effect of treatment $\left(\mathrm{F}_{(1,37)}=13.9\right.$; $p<0.001)$. Post hoc analyses revealed that rats receiving either the lower $(10 \mathrm{ng} / 0.5 \mu \mathrm{l})$ or higher $(100 \mathrm{ng} / 0.5 \mu \mathrm{l})$ dose of NAD 299 (10 ng, $n=7 ; 100 \mathrm{ng}, n=6$ ) with CBD, demonstrated robust associative freezing behaviors in response to $\mathrm{CS}+$ presentations, relative to $\mathrm{VEH}$ controls $(n=7, p$ 's $<0.01$; Figure $2 b)$. To control for the potential effects of NAD 299 alone, a separate control group received bilateral intra-NASh NAD 299 (100 ng/0.5 $\mu \mathrm{l} ; n=8)$ alone, before training. These rats displayed normal conditioned freezing behavior, freezing significantly more to CS+ presentations $(p<0.05)$. Next, to examine the possible involvement of DA receptor transmission in the effects of intra-NASh CBD, we challenged the effects of intra-NASh CBD with the broad spectrum DA receptor antagonist, $\alpha$-flu $(100-1000 \mathrm{ng} / 0.5 \mu \mathrm{l})$. ANOVA revealed a significant main effect of group $\left(\mathrm{F}_{(3,50)}=5.65 ; p<0.01\right)$ on times spent freezing to CS+ vs CS - presentations. Post hoc analyses revealed that rats receiving coadministration of $\mathrm{CBD}$ $(100 \mathrm{ng} / 0.5 \mu \mathrm{l})$ with either the lower dose of $\alpha$-flu (100 ng/ $0.5 \mu \mathrm{l} ; n=6)$ or the higher dose of $\alpha$-flu $(1000 \mathrm{ng} / 0.5 \mu \mathrm{l}$; $n=8$ ) showed no associative freezing during CS+ presentations ( $p$ 's $>0.05$; Figure $2 b$ ). To control for any potential effects of $\alpha$-flu alone on fear memory formation, a separate control group $(n=8)$ received intra-NASh $\alpha$-flu alone (1000 ng/0.5 $\mu \mathrm{l})$. This group demonstrated significant associative freezing behaviors $(p<0.05$; Figure 2b). Thus, whereas $5-\mathrm{HT}_{1 \mathrm{~A}}$ receptor blockade reversed the effects of CBD-induced block of fear memory acquisition, DA receptor blockade had no effect. In addition, neither the highest behaviorally effective doses of NAD 299 nor $\alpha$-flu produced any effects on fear memory acquisition in and of themselves.

Beyond the 5- $\mathrm{HT}_{1 \mathrm{~A}}$ receptor system, previous studies have suggested that $\mathrm{CBD}$ may produce pharmacological actions on the CB1 receptor system (McPartland et al, 2015). To examine if the effects of $\mathrm{CBD}$ on fear memory acquisition may be mediated through a $\mathrm{CB} 1$ receptor substrate, separate groups of rats received intra-NASh CBD (100 ng/0.5 $\mu \mathrm{l})$ coadministered with the selective CB1 antagonist, RIM (50-500 ng/0.5 $\mu \mathrm{l} ; n=9, \quad n=10$, respectively). Comparing the effects of RIM/CBD coadministration on freezing behaviors revealed a significant effect of group $\left(\mathrm{F}_{(2,47)}=10.53 ; p<0.01\right)$, with post hoc analyses revealing that neither dose of RIM reversed the effects of CBD on fear memory blockade, relative to $\mathrm{VEH}$ controls, with both groups displaying no associative freezing in response to CS+ vs CS - presentations ( $p$ 's $>0.05$; Figure $2 \mathrm{~b}$ ).

To ensure that the highest doses of CBD, NAD 299, or $\alpha$-flu were not producing any unconditioned effects on footshock sensitivity during the fear memory acquisition phase, separate control groups received footshock sensitivity tests (see Materials and Methods) following bilateral intraNASh microinfusions of VEH $(n=8), \mathrm{CBD}(100 \mathrm{ng} / 0.5 \mu \mathrm{l}$, $n=7$ ), NAD 299 (500 ng/0.5 $\mu \mathrm{l}, n=8$ ), or $\alpha$-flu (1000 ng/ $0.5 \mu \mathrm{l}, n=8)$. Group comparisons with ANOVA revealed no significant group differences in the amount of freezing behavior following footshock $(0.8 \mathrm{~mA})$ administration $\left(\mathrm{F}_{(3,29)}=1.10 ; p>0.05\right.$; Figure $\left.2 \mathrm{c}\right)$; total distance traveled during the sensitivity testing $\left(\mathrm{F}_{(3,29)}=0.92 ; p>0.05\right.$; Figure 2d) or total average number of jumping events during footshock administrations $\left(\mathrm{F}_{(3,29)}=0.25 ; p>0.05\right.$; Figure 2e). Thus, neither CBD, NAD 299 nor $\alpha$-flu produced any observable alterations in footshock sensitivity during fear memory acquisition training. 
a

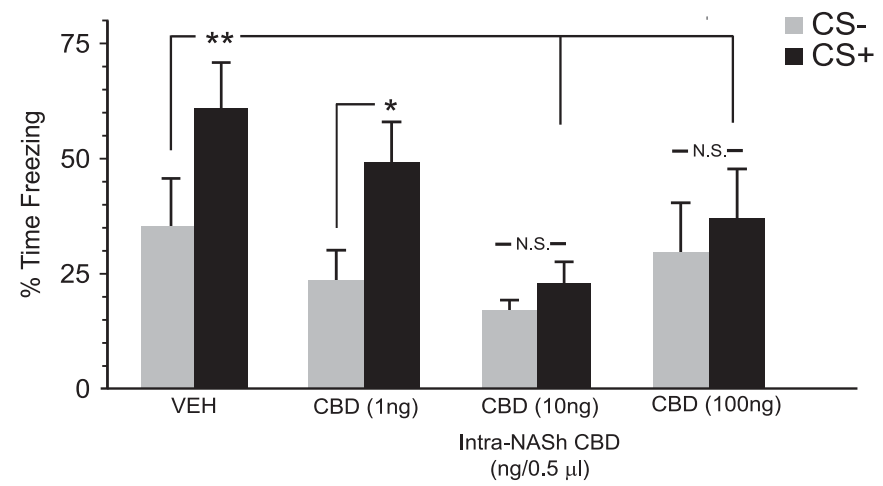

b
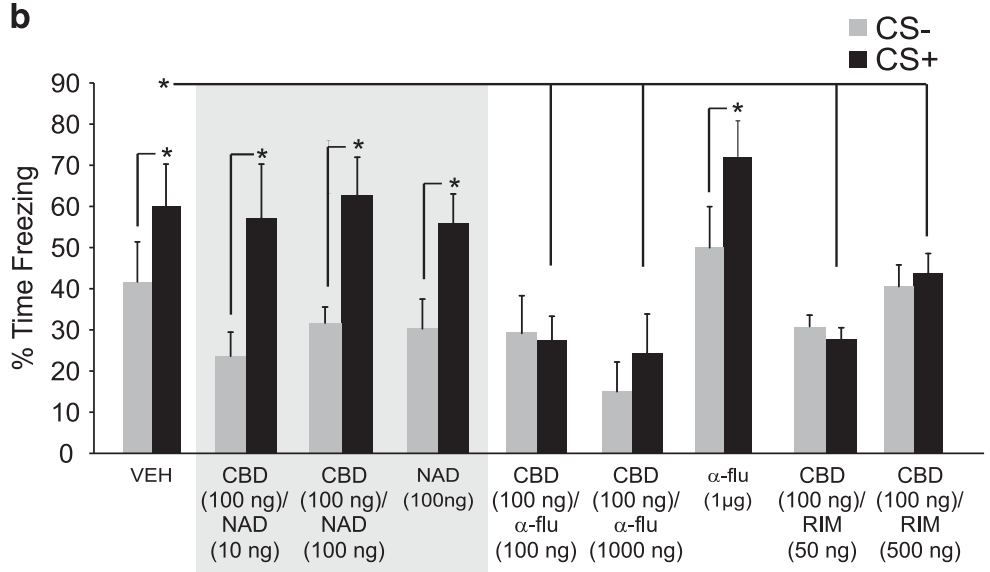

C

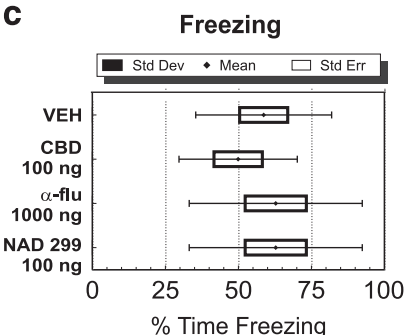

d

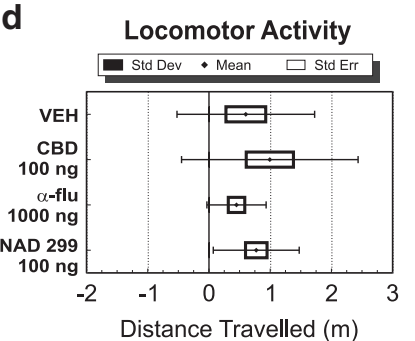

e

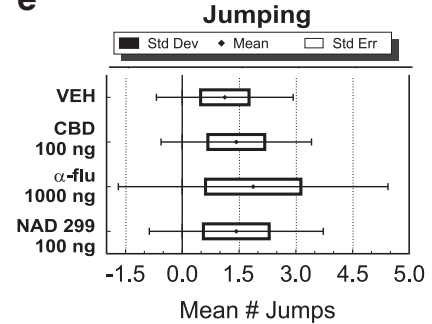

Figure 2 Effects of intra-shell region of the mesolimbic nucleus accumbens (NASh) cannabidiol (CBD) on conditioned freezing behaviors: modulation by serotonin IA receptor (5-HTIA) receptor transmission. (a) Relative to vehicle $(V E H)$ control rats $(n=6)$, bilateral administration of intra-NASh CBD (I ng, $n=7 ; 10 n g, n=8$ or $100 n g / 0.5 \mu l, n=6)$ dose-dependently blocks the acquisition of suprathreshold (0.8 mA) olfactory associative fear memory. (b) The effects of intra-NASh CBD on associative fear memory formation are dose-dependently reversed by coadministration of a selective 5-HTIA receptor antagonist (NAD 299, $10 \mathrm{ng}, n=7 ; 100 \mathrm{ng} / 0.5 \mu \mathrm{l}, n=6$ ), but not by the broad-spectrum dopamine (DA) receptor antagonist, $\alpha$-flu (I $00 \mathrm{ng}(\mathrm{n}=6$ ), I $000 \mathrm{ng} /$ $0.5 \mu \mathrm{l}(n=8)$ ), or the CBI receptor-selective antagonist, RIM (50 ng $(n=9), 500 \mathrm{ng} / 0.5 \mu \mathrm{l}, n=10)$. Neither intra-NASh NAD $299(500 \mathrm{ng}, n=8)$ nor $\alpha$-flu ( 1000 ng, $n=8$ ) administered alone produce any effects on fear memory formation. Separate footshock sensitivity control groups (see Materials and Methods) receiving VEH $(n=8)$ or the effective doses of intra-NASh CBD (I00 ng, $n=7), \alpha$-flu (I000 ng, $n=8$ ), or NAD 299 (I00 ng, $n=8)$ revealed no significant differences in measures of (c), freezing behavior, (d), locomotor activity or (e), jumping behaviors. $* p<0.05$; *** $<0.0$ I. Bars represent means \pm S.E.M. for this and all subsequent figures. CS, conditioned stimulus (positive or negative).

\section{Intra-NASh CBD Modulates DAergic vs Non-DAergic Neuronal Activity States in the VTA}

We next performed in vivo, single-unit neuronal recordings in the VTA to determine the potential effects of intra-NASh CBD administration on spontaneous neuronal activity patterns in isolated populations of DAergic $v s$ non-DAergic VTA neurons (see Materials and Methods; Figure 3a). Accordingly, our previously determined behaviorally effective dose of CBD (100 ng) was microinfused into the NASh while simultaneously recording single-cell extracellular VTA neuronal units. A total of $n=15$ VTA-DA neurons were recorded and analyzed following intra-NASh CBD microinfusions. A cell was considered to have changed its firing rate if there was a minimum of $10 \%$ difference in frequency rate from baseline. Using this previously established and reported criterion (Draycott et al, 2014; Tan et al, 2009), qualitative analysis revealed that $60 \%$ of DA neurons showed decreased activity, $7 \%$ increased, and 33\% were unchanged (Figure 3b). Subgroup analyses of average frequency recorded during $5 \mathrm{~min}$ pre- $v s$ post-intra-NASh microinfusions revealed that $\mathrm{CBD}$ significantly decreased the firing 
a

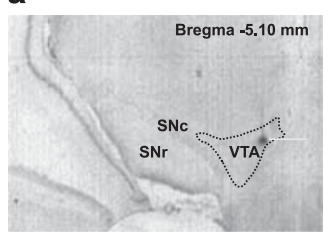

C

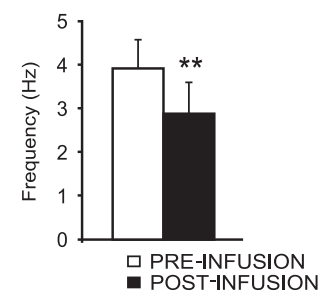

e

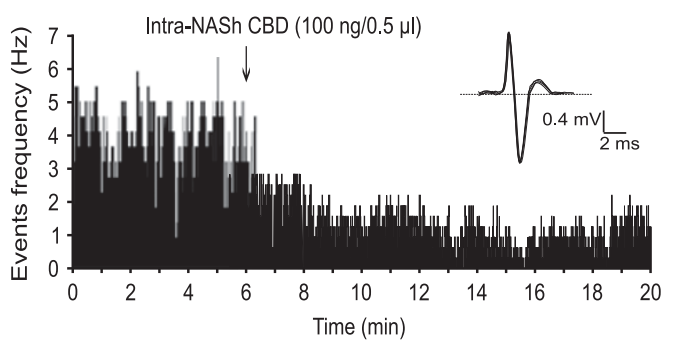

f
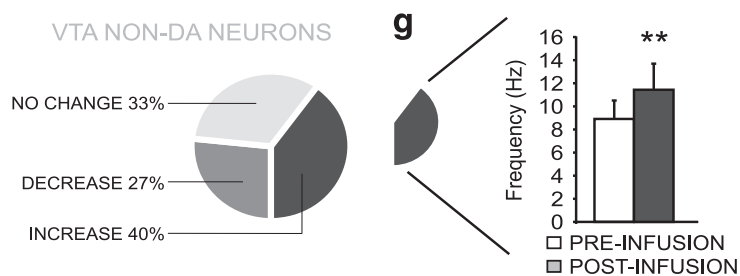

h

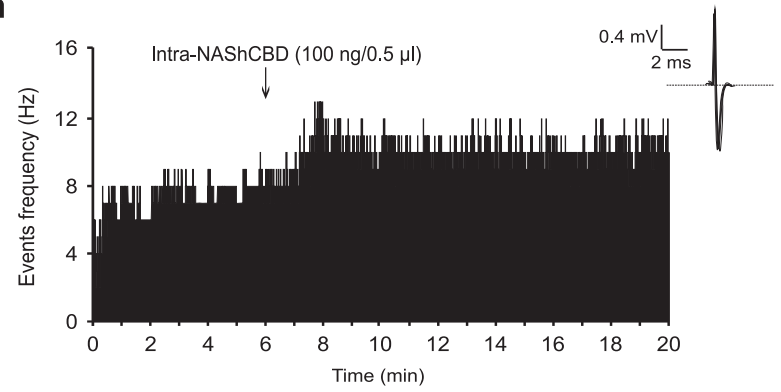

Figure 3 Effects of intra-shell region of the mesolimbic nucleus accumbens (NASh) cannabidiol (CBD) on DAergic and non-DAergic neuronal activity patterns in the ventral tegmental area (VTA). (a) Representative microphotograph showing typical intra-VTA in vivo dopamine (DA) neuron recording location (indicated by arrow). (b) Group summary of all VTA DA neuronal effects $(n=15)$ showing distribution of neuronal response patterns (no change in frequency, decreased activity, increased activity) across experimental conditions. (c) Intra-NASh CBD significantly decreased spontaneous VTA DA neuronal firing frequency and (d) bursting rates. (e) Sample rastergram showing typical VTA DAergic neuronal response pattern following intra-NASh CBD $(\mid 00 \mathrm{ng} / 0.5 \mu \mathrm{l})$ administration. (f) Summary of non-DA neuronal group response patterns following intra-NASh CBD administration $(n=15)$. (g) A sub-population of non-DAergic VTA neurons show a significant increase in spontaneous firing frequency following intra-NASh CBD (I00 ng/0.5 $\mu$ l). (h) Sample rastergram showing a typical VTA non-DA neuronal response pattern following intra-NASh CBD administration. $* p<0.05$; $* * * 0.01$. CS, conditioned stimulus (positive or negative). rate $\left(t_{(14)}=3.13, p<0.01\right.$; Figure $\left.3 c\right)$ and bursting rate $\left.t_{(14)}=2.76, p<0.05\right)$ without significantly decreasing the number of spikes per burst $\left(t_{(14)}=2.06, p=0.06\right.$ ) (Figure $3 \mathrm{~d}$ ). Thus, intra-NASh CBD (100 ng) causes a predominantly inhibitory effect on VTA DAergic neuronal frequency and bursting rates. In Figure $3 \mathrm{e}$, we present a rastergram of a single VTA DA neuron showing a typical decreased activity pattern following intra-NASh CBD microinfusion.

We next recorded and analyzed presumptive VTA GABA neurons $(n=15)$ during intra-NASh CBD (100 ng) administration. Qualitative analysis of overall population activity revealed that $27 \%$ of non-DA neurons decreased activity, $40 \%$ increased, and $33 \%$ demonstrated no significant change in frequency (Figure 3f). Statistical analyses of neuronal subpopulations recorded $5 \mathrm{~min}$ pre- $v s$ post-NASh microinfusions showed that while CBD did not significantly modify the collective (group) firing frequency of VTA GABA interneurons, $t_{(14)}=0.04 ; p=0.97$, separate sub-population analyses revealed that neurons showing increased activity were significantly elevated in firing frequency relative to baseline $\left(t_{(5)}=3.8 ; p<0.01\right.$; Figure $\left.3 g\right)$, whereas neurons showing either decreased $\left(t_{(3)}=2.9 ; p>0.05\right)$ or no change in activity $\left(t_{(4)}=0.55 ; p>0.05\right)$ were not significantly changed from preinfusion baseline levels (data not shown). Collectively, these data demonstrate that intra-NASh CBD induces heterogeneous effects on presumptive VTA GABAergic neurons. However, a plurality of these neurons (40\%) significantly increased their spontaneous firing rates. In Figure $3 \mathrm{~h}$, we present a rastergram showing a typical nonDAergic neuronal response pattern following intra-NASh CBD microinfusion.

\section{CBD Modulates DAergic Neuronal Activity in the VTA Selectively Through NASh $5-\mathrm{HT}_{1 \mathrm{~A}}$ Transmission}

We next sought to determine how the effects of coadministration of selective $5-\mathrm{HT}_{1 \mathrm{~A}}$ or $\mathrm{DA}$ receptor antagonists on CBD-mediated behaviors might influence VTA DAergic neuronal activity. Accordingly, we performed in vivo, singleunit intra-VTA neuronal recordings to determine the potential effects of intra-NASh CBD, NAD 299/CBD, or $\alpha$-flu/CBD coadministration on VTA DA neuron firing frequency and bursting levels (see Materials and Methods), using our behaviorally effective doses of CBD (100 ng/0.5 $\mu \mathrm{l})$, NAD $299(100 \mathrm{ng} / 0.5 \mu \mathrm{l})$, or $\alpha$-flu $(1 \mu \mathrm{g} / 0.5 \mu \mathrm{l})$. We sampled a total of $n=44$ VTA DA neurons (VEH group, $n=10$ cells; CBD (100 ng) group, $n=15$ cells; CBD (100 ng)+NAD 299 (100 ng) group, $n=10$ cells; CBD (100 ng) $+\alpha$-flu (1000 ng), $n=9$ cells). A summary of VTA DAergic neuronal activity profiles after intra-NASh microinfusions are represented in Figures 4a. For rats receiving intra-NASh VEH, 50\% of neurons showed no change, 30\% increased, and 20\% showed decreased activity. For rats receiving intra-NASh CBD, $60 \%$ of neurons decreased firing frequency, $33 \%$ showed no change, and $7 \%$ increased frequency. In rats receiving intraNASh CBD+NAD 299, neurons decreasing, increasing, or showing no change in activity levels were $60 \%, 20 \%$, and $20 \%$, respectively. In rats microinfused with $\mathrm{CBD}+\alpha$-flu, $78 \%$ of the recorded cells decreased their firing frequency, $22 \%$ showed no change, and no cells demonstrated increased frequency. Analyses of pre- $v s$ postinfusion activity rates for VTA DA neurons revealed average changes from baseline of 

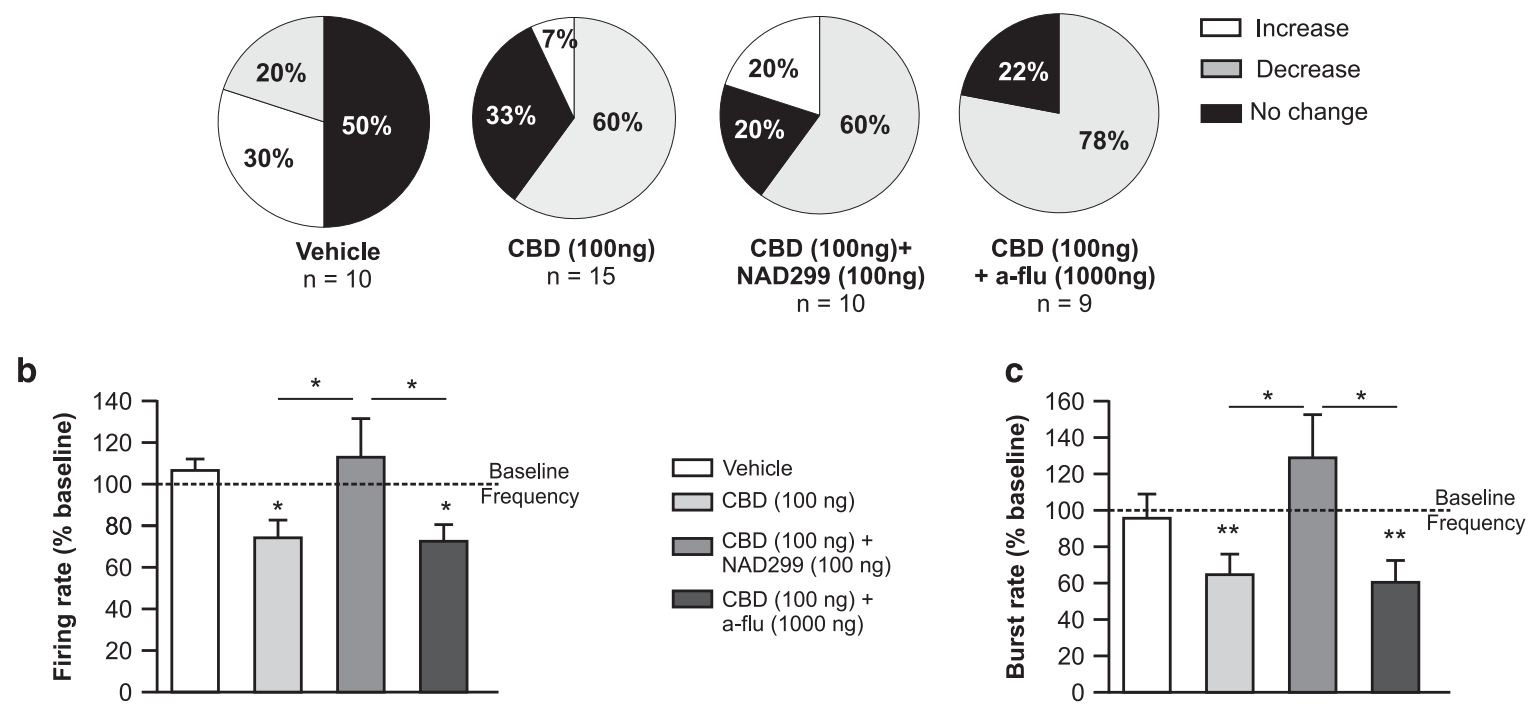

d

Neuronal activity profile (in \%)
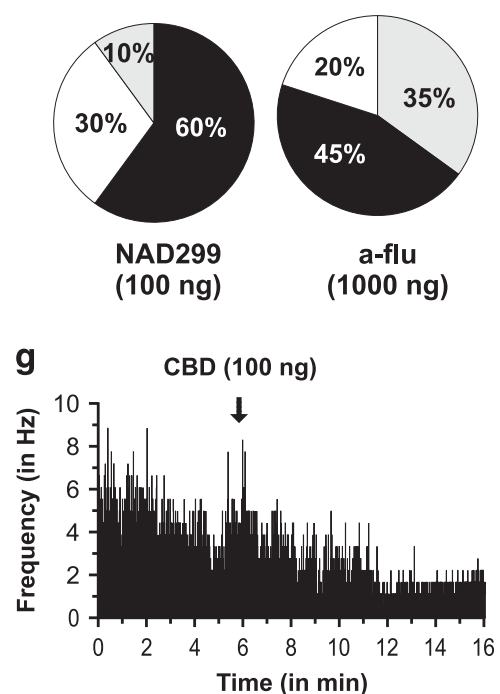
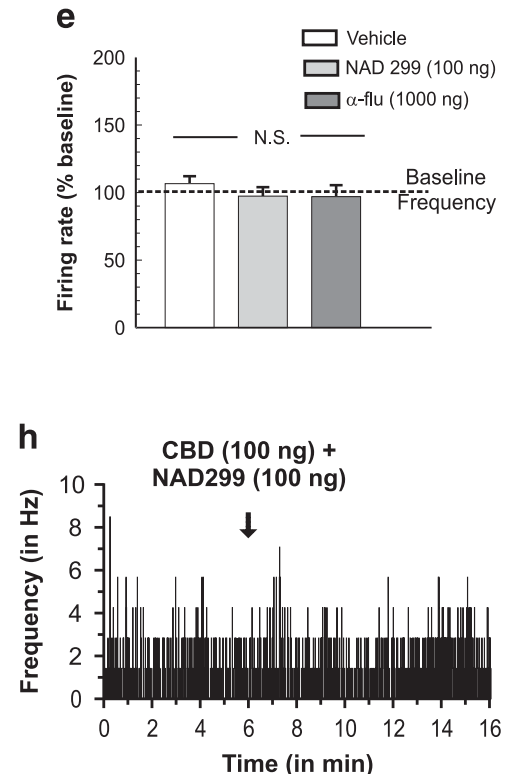
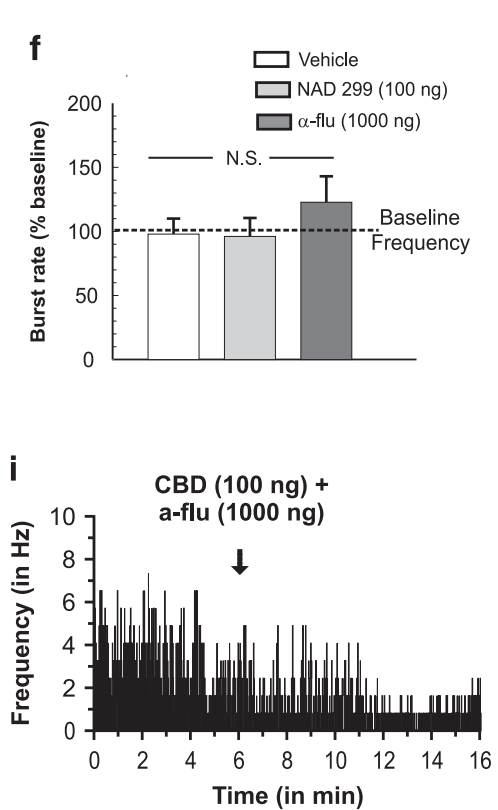

Figure 4 Effects of intra-shell region of the mesolimbic nucleus accumbens (NASh) cannabidiol (CBD) and serotonergic/dopaminergic antagonists on VTA DAergic neuronal activity patterns in the ventral tegmental area (VTA). (a) Summary of experimental neuronal groups showing relative changes (no change, increase or decrease) firing frequencies following intra-NASh pharmacological treatments (total $n=44$ neurons sampled). (b) Intra-NASh CBD alone (I 00 ng/ $0.5 \mu l)$ caused a significant decrease in spontaneous VTA dopamine (DA) neuronal firing frequency rates. This inhibitory effect was reversed by coadministration of the effective dose of NAD 299 (500 ng/0.5 $\mu$ l). In contrast, coadministration with the DA receptor antagonist, $\alpha$-flu (I $\mu g / 0.5 \mu l)$, had no effect on CBD's inhibition of VTA DA neuron activity. (c) Comparing VTA DA neuron bursting rates revealed that intra-NASh CBD (I 00 ng/0.5 $\mu$ l) significantly decreases VTA DA neuron bursting rates. Again, this effect was significantly reversed with coadministration of NAD 299 (500 ng/0.5 $\mu$ ). In contrast, coadministration with the DA receptor antagonist, $\alpha$-flu $(I \mu \mathrm{g} / 0.5 \mu \mathrm{l})$, had no effect on CBD's inhibition of VTA DA neuron bursting rates. (d) Intra-NASh NAD 299 (500 ng) or $\alpha$-flu ( 1000 ng) produced heterogeneous effects on spontaneous VTA DA neuron activity patterns. However, neither drug alone produced any significant effects on firing frequency (e) or bursting rates (f). (g) Sample rastergram showing a typical VTA DA neuron inhibitory response pattern following intra-NASh CBD. (h) Sample rastergram showing a typical VTA DA neuron response following coadministration of CBD with NAD 299 and (i) sample rastergram showing a typical response pattern following coadministration of CBD with $\alpha$-flu. $* p<0.05$; $* * p<0.0$ I. CS, conditioned stimulus (positive or negative).

$+7 \%$ for rats treated with $\mathrm{VEH},-27 \%$ for rats treated with $\mathrm{CBD},+3 \%$ with $\mathrm{CBD}+\mathrm{NAD} 299$, and $-23 \%$ for rats microinfused with $\mathrm{CBD}+\alpha$-flu (Figure $4 \mathrm{~b}$ ). ANOVA comparing groups revealed a significant main effect of treatment on VTA DA neuron firing frequency rates $\left(\mathrm{F}_{(3,43)}=3.57\right.$, $p<0.05)$. Post hoc analysis revealed that rats treated with intra-NASh $\mathrm{CBD}$ alone or with CBD+ $\alpha$-flu showed significantly decreased firing frequencies relative to baseline (p's <0.05). However, rats treated with CBD+NAD 299 showed significantly increased firing frequency relative to these groups, and no significant difference from baseline levels ( $p<0.05$; Figure 4b). Thus, cotreatment with NAD 299, but not $\alpha$-flu, reversed CBD-induced reductions in spontaneous DA neuron frequency rates. 
Analysis of VTA DA neuron bursting rates revealed average changes from baseline of $-4 \%,-35 \%,+29 \%$, and $-40 \%$ for rats treated with intra-NASh VEH, CBD, CBD+NAD 299, and $\mathrm{CBD}+\alpha$-flu, respectively (Figure $4 \mathrm{c}$ ). ANOVA comparing groups revealed a significant effect of treatment $\left(\mathrm{F}_{(3,43)}=4.24\right.$, $p<0.01)$ and post hoc comparisons showed that bursting rates were significantly different between rats treated with CBD vs CBD+NAD $299(p<0.05)$ and between CBD $+\alpha$-flu and CBD + NAD 299 groups $(p<0.05)$. Thus, cotreatment with NAD 299 , but not $\alpha$-flu, reversed CBD-induced reductions in spontaneous DA neuron bursting rates. Next, to examine if intra-NASh $\alpha$-flu or NAD 299 had any effects on VTA DA neuron frequency or bursting rates in and of themselves, separate control groups received either intra-NASh NAD 299 (500 ng/0.5 $\mu \mathrm{l} ; n=10$ neurons) or $\alpha$-flu (1000 ng/0.5 $\mu \mathrm{l} ; n=9$ neurons). For intra-NASh NAD 299, qualitative analysis revealed that $10 \%$ of neurons showed increased, $30 \%$ decreased, and $60 \%$ no change in frequency (Figure $4 \mathrm{~d}$ ). For intra-NASh $\alpha$-flu, qualitative analysis revealed that $20 \%$ of neurons increased, $35 \%$ decreased, and $45 \%$ showed no changes (Figure $4 \mathrm{~d}$ ). ANOVA revealed no significant treatment effect on VTA DA neuron firing rates across groups $\left(\mathrm{F}_{(2,28)}=0.63 ; p>0.05 ;\right.$ Figure $\left.4 \mathrm{e}\right)$. ANOVA analysis of bursting rates similarly revealed no significant treatment effect on DA neuron burst rates across groups $\left(\mathrm{F}_{(2,26)}=1.33\right.$; $p>0.05$; Figure 4f). Thus, neither intra-NASh NAD 299 nor $\alpha$-flu had any effects on VTA DA neuron activity parameters in and of themselves.

Representative neuronal rastergrams showing single VTA DA neuronal response patterns following intra-NASh CBD (100 ng alone; Figure 4g); CBD (100 ng)+NAD 299 (100 ng; Figure $4 \mathrm{~h})$; and CBD (100 ng) $+\alpha$-flu (1000 ng; Figure $4 \mathrm{i}$ ) demonstrate typically observed neuronal activity patterns following these treatments. Taken together, these results show that intra-NASh CBD decreases VTA DA neuronal frequency and bursting rates. These effects were blocked by coinfusion of a $5-\mathrm{HT}_{1 \mathrm{~A}}$ antagonist, but remained unchanged by the coinfusion of a DA receptor antagonist.

\section{Functional Disconnection of the NASh $\rightarrow$ VTA Pathway Reverses the Effects of Intra-NASh CBD on Fear Memory Formation}

Medium spiny neurons (MSNs) in the NAc send GABAergic terminals to VTA neurons (Nauta et al, 1978; Kalivas et al, 1993). Given our previously described finding (Figures 3f-h) that intra-NASh CBD caused significant increases in non-DA, presumptive VTA GABAergic neurons, we hypothesized that the behavioral effects of intra-NASh CBD may depend on $\mathrm{NAc} \rightarrow$ VTA GABAergic projections and therefore depend on GABA receptor transmission directly in the VTA. Accordingly, using a functional cerebral disconnection procedure (see Materials and Methods), we examined whether intra-VTA blockade of GABAergic transmission may modulate the ability of intra-NASh CBD to block associative fear memory in rats with unilateral cannulae implantations into the NASh and VTA. Rats received a combination of intra-VTA bicuculline (50 ng) and saclofen (100 ng) to block intra-VTA $\mathrm{GABA}_{\mathrm{A} / \mathrm{B}}$ receptor transmission immediately before a unilateral microinfusion of intra-NASh CBD (100 ng) in the contralateral hemisphere (Figure 5a). Histological analysis revealed intraVTA injector locations within the anatomical boundaries of the VTA or NASh as defined by Paxinos and Watson (2005) (Figures $5 \mathrm{~b}$ and c). ANOVA comparing behavioral associative freezing scores across groups revealed a significant main effect of group $\left(\mathrm{F}_{(3,38)}=3.261 ; p \leq 0.05\right.$; Figure $\left.5 \mathrm{~d}\right)$ on percentages of time spent freezing to either CS+ or CS - presentations. Post hoc analyses revealed that $\mathrm{VEH}$ control rats (NASh/VEH vs $\mathrm{VTA} / \mathrm{VEH} ; n=6)$ demonstrated robust associative freezing behaviors in response to $\mathrm{CS}+$ presentations $(p<0.01)$. In contrast, rats receiving the intra-NASh CBD $(n=6 ; 100 \mathrm{ng} /$ $0.5 \mu \mathrm{l}$ ) with intra-VTA VEH showed no associative fear memory $(p>0.05)$, consistent with previous results. However, rats receiving intra-VTA $\mathrm{GABA}_{\mathrm{A} / \mathrm{B}}$ antagonists before intraNASh CBD $(100 \mathrm{ng} / 0.5 \mu \mathrm{l}) \quad(n=6)$ demonstrated robust associative freezing behaviors in response to $\mathrm{CS}+$ presentations $(p<0.05)$, demonstrating that contralateral blockade of VTA $\mathrm{GABA}_{\mathrm{A} / \mathrm{B}}$ transmission is sufficient to reverse the behavioral effects of intra-NASh CBD on blockade of associative fear memory formation. Finally, to ensure that intra-VTA GABA $A$ / $B$ receptor blockade did not in itself influence fear memory formation, a separate group received intra-VTA $\mathrm{GABA}_{\mathrm{A} / \mathrm{B}}$ antagonist treatment before intra-NASh VEH. Similar to VEH/ $\mathrm{VEH}$-treated controls, these rats displayed significant associative fear responses during $C S+$ presentations $(n=6 ; p<0.05)$.

\section{DISCUSSION}

In the present study, we report that intra-NASh CBD blocks the formation of fear-related memory via a $5-\mathrm{HT}_{1 \mathrm{~A}}$ receptordependent mechanism. Furthermore, we found that intraNASh CBD decreased spontaneous VTA DAergic neuronal activity, both in terms of frequency and bursting levels, and conversely, increased the spontaneous activity of nonDAergic, presumptive VTA GABAergic neurons. CBD's modulation of VTA DAergic neuronal activity was dependent on intra-NASh $5-\mathrm{HT}_{1 \mathrm{~A}}$ transmission, but not DAergic or $\mathrm{CB} 1$ receptor transmission, as only blockade of $5 \mathrm{HT}_{1 \mathrm{~A}}$ transmission reversed the effects of CBD on VTA DAergic activity states and restored associative fear memory formation. Finally, consistent with our electrophysiological findings, functional disconnection of GABAergic transmission between the contralateral NASh and VTA reversed the effects of intra-NASh CBD on associative fear memory formation. Taken together, these findings demonstrate several new insights into the potential role for CBD in the modulation of emotional memory processing within the mesolimbic pathway, implicating serotonergic transmission as an important mediator of these effects.

Our findings are consistent with previous research demonstrating a role for CBD in modulating emotional memory. For example, Stern et al (2012) reported that systemically administered CBD could block reconsolidation of associative fear memories in rats in a temporally specific manner. Das et al (2013) reported that systemic CBD could enhance the consolidation of fear-related extinction learning in human subjects. Marinho et al (2015) recently reported that CBD microinfusions into the prelimbic or infralimbic regions of rat prefrontal cortex could induce either anxiolytic or anxiogenic effects through a $5-\mathrm{HT}_{1 \mathrm{~A}}$-dependent mechanism. The present findings are the first report that $\mathrm{CBD}$ can produce effects on fear-memory acquisition directly in the NAc, via $5-\mathrm{HT}_{\mathrm{A}^{-}}$ dependent modulation of VTA neuronal activity. 
a

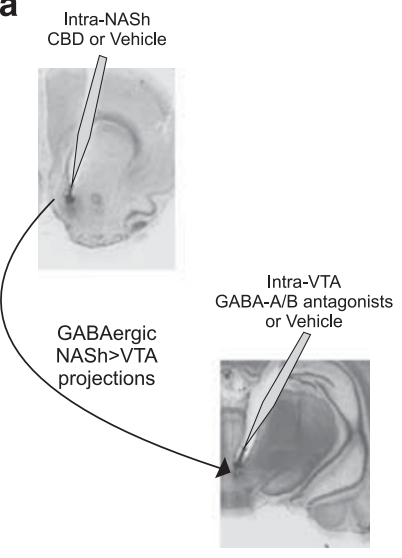

b
Intra-VTA
Placements
Intra-NASh
Placements

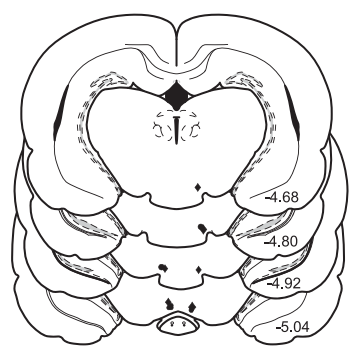

C

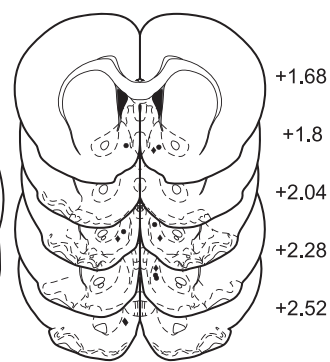

d

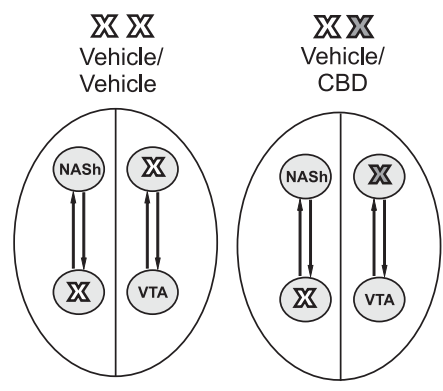

e

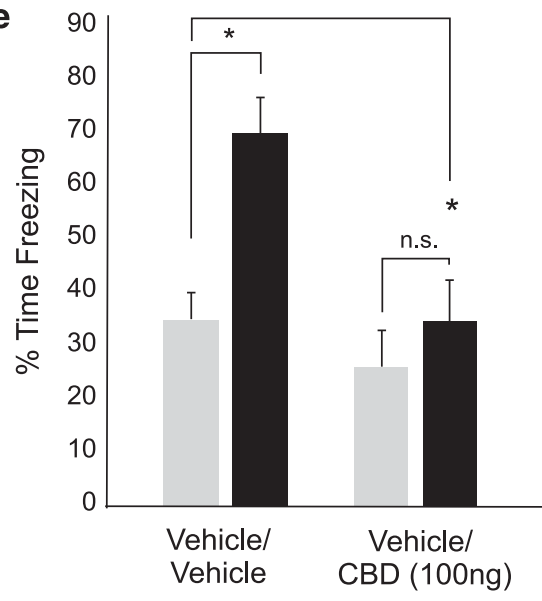

$\mathbf{x} x$

Saclofen/Bicuculine/
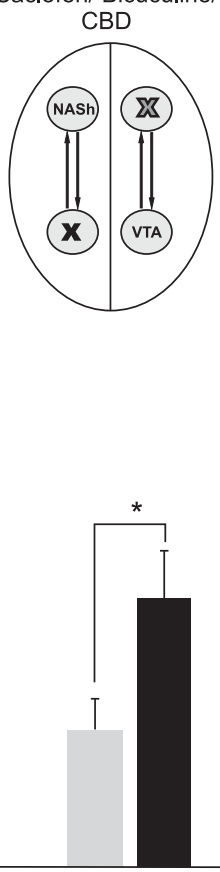

Saclofen(50ng)

Bicuculline(50ng)

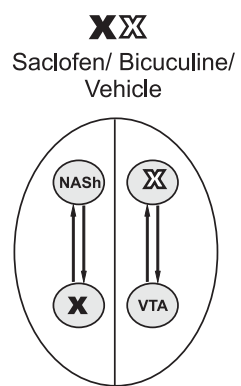

CS-

Figure 5 Disconnection of shell region of the mesolimbic nucleus accumbens/ventral tegmental area (NASh/NTA) $\gamma$-aminobutyric acid, type A/B $\left(G A B A_{A / B}\right)$ transmission reverses the effects of intra-NASh cannabidiol (CBD) on conditioned freezing. (a) Summary of experimental design for NASh-VTA disconnection procedure with sample microphotographs showing representative intra-VTA and intra-nucleus accumbens (NAc) microinjector placements. $(b$ and $c)$ Schematic summaries showing unilateral placements for intra-VTA microinfusions of the GABA $A B$ antagonist mixture and intra-NASh CBD microinfusion locations (see Materials and Methods). $=100 \mathrm{ng} C B D+50 \mathrm{ng}$ saclofen/50 ng bicuculine group, $\$=100 \mathrm{ng} C B D+$ saline group. (d) Schematic representation of experimental groups with description of contralateral intra-VTA vs intra-NASh treatments. (e) Consistent with previous results (Figure 2a), intra-NASh CBD effectively blocks formation of associative fear memory in rats receiving intra-NASh CBD vs contralateral intra-VTA vehicle $(V E H)(n=6)$, relative to $\mathrm{VEH} / \mathrm{VEH}$ controls $(n=6)$. In contrast, rats receiving intra-NASh CBD vs intra-VTA GABA $/ B$ receptor blockade in the contralateral hemisphere $(n=6)$ show no blockade of fear memory formation. In addition, rats receiving intra-NASh CBD vs contralateral VTA GABA $A B B$ receptor blockade $(n=6)$ demonstrate normal fear memory formation. ${ }^{*} p<0.05$. CS, conditioned stimulus (positive or negative).

\section{CBD Modulates Conditioned Freezing Behavior Through a $5-\mathrm{HT}_{1 \mathrm{~A}}$-Dependent Mechanism in the NAc}

Considerable evidence links the pharmacological and behavioral effects of $\mathrm{CBD}$ to the serotonergic system. For example, $\mathrm{CBD}$ is a $5-\mathrm{HT}_{1 \mathrm{~A}}$ receptor agonist (Russo et al, 2005) and systemic CBD modulates the reward-facilitating effects of morphine via $5-\mathrm{HT}_{1 \mathrm{~A}}$ receptors in the dorsal raphe nucleus (Katsidoni et al, 2013). In addition, CBD has been shown to modulate anxiety-like behaviors through actions on the $5-\mathrm{HT} 1_{\mathrm{A}}$ receptor (Fogaca et al, 2014; Marinho et al, 2015). Consistent with the current findings, previous evidence has demonstrated that CBD's ability to interact with the mesolimbic system involves $5-\mathrm{HT}_{1 \mathrm{~A}}$ receptor 
transmission. For example, $5-\mathrm{HT}_{1 \mathrm{~A}}$ activation in the NASh blocks apomorphine-induced behaviors in rodents (Fujita et al, 2008), inhibits amphetamine-induced DA release in the rat NAc (Ichikawa et al, 1995), and reduces striatal DA synthesis (Johnson et al, 1993). Given these effects of $5-\mathrm{HT}_{1 \mathrm{~A}}$ activation, blockade of $5-\mathrm{HT}_{1 \mathrm{~A}}$ transmission would be expected to counteract the effects of $\mathrm{CBD}$, removing the inhibitory effects of intra-NASh CBD on VTA DAergic activity. This prediction is consistent with our electrophysiological findings showing that blockade of $5-\mathrm{HT}_{1 \mathrm{~A}}$ transmission restores VTA DAergic tone in the presence of $\mathrm{CBD}$ and reverses the behavioral effects of $\mathrm{CBD}$ on fear memory formation. In contrast, coadministration of a DA receptor antagonist or selective $\mathrm{CB} 1$ receptor antagonist failed to reverse the behavioral effects of CBD. Previous studies have reported that $\mathrm{CBD}$ can act as an antagonist or inverse agonist of the CB1 receptor (Thomas et al, 1998; Pertwee, 2008). However, other reports have found that CBD has relatively low binding affinity and/or activity at the CB1 receptor (Bisogno et al, 2001; Thomas et al, 2007). The present findings would suggest that, at least within the NASh, CBD produces its effects through non-CB1 receptordependent mechanisms.

\section{CBD Modulates Neuronal Activity Patterns in the VTA Through a 5-HT ${ }_{1 \mathrm{~A}}$-Dependent Mechanism}

Interestingly, previous studies using systemic CBD administration have reported both effects of CBD on spontaneous activity patterns in VTA neuronal populations (French et al, 1997) or increases in mesolimbic DA release (MurilloRodríguez et al, 2006). These discrepancies are likely due to differences in administration routes, as the present study exclusively used targeted microinfusions into the NASh $v s$ systemic administration. However, it is of interest that systemically applied CBD may be interacting with neural circuits extrinsic to the mesocorticolimbic system, which may in turn produce different effects on DAergic transmission patterns.

Within the VTA, we found that behaviorally effective doses of intra-NASh CBD were sufficient to inhibit VTA DAergic activity levels while simultaneously increasing the activity states of presumptive inhibitory VTA GABAergic neurons. This effect is consistent with previous observations demonstrating that blunting or potentiating VTA DAergic neuronal activity can potently modulate the formation of associative fear memories. For example, we have reported that activation of $\mathrm{CB} 1$ receptors in the rat prefrontal cortex can simultaneously block the formation of normally suprathreshold conditioned freezing behaviors and inhibit subcortical DAergic activity (Draycott et al, 2014). In contrast, overstimulation of DAergic transmission in the PFC can amplify normally non-salient associative fear conditioning cues (Lauzon et al, 2009). The present findings suggest that intra-accumbal modulation of VTA DAergic activity via $\mathrm{CBD} / 5-\mathrm{HT}_{1 \mathrm{~A}}$-dependent mechanisms may similarly regulate emotional salience and the acquisition of conditioned freezing behavior via functional interactions with select VTA neuronal populations. For example, by blunting VTA DAergic neuronal activity during the acquisition of associative fear memory, CBD may serve to block conditioned freezing behaviors. Future studies are required to more precisely characterize the effects of CBD across these distinct learning phases of emotional memory processing.

How might accumbal $5 \mathrm{HT}_{1 \mathrm{~A}}$ transmission modulate upstream DAergic mesolimbic transmission? Anatomical evidence demonstrates that NAc GABAergic MSNs send functional GABAergic projections to the VTA (Nauta et al, 1978; Kalivas et al, 1993). In the present study, we found that intra-NASh CBD increased the activity rates of presumptive, non-DA GABAergic neurons in the VTA. Accordingly, we hypothesized that intra-NASh $\mathrm{CBD}$ may regulate VTA DAergic activity (and corresponding fear-related associative memory formation) via indirect modulation of GABAergic transmission substrates in the VTA. To test this, we performed a disconnection study wherein intra-NASh CBD effects were disconnected from the contralateral hemisphere with combined intra-VTA microinfusions of $\mathrm{GABA}_{\mathrm{A} / \mathrm{B}}$ receptor antagonists. Consistent with this hypothesis, disconnection blockade of VTA GABAergic transmission was capable of reversing the effects of intra-NASh CBD on fear memory formation. While beyond the scope of the present study, one interesting implication from the present results is that $5-\mathrm{HT}_{1 \mathrm{~A}}$ receptor activation within the NASh might similarly modulate downstream VTA neuronal activity states and fear memory formation. Future studies are required to investigate these possibilities.

\section{Implications of CBD's Modulatory Role on Mesolimbic Activity}

The present study adds to a growing body of preclinical and clinical evidence demonstrating that $\mathrm{CBD}$ can modulate activity states of the mesolimbic DA system, and, in turn, regulate emotional processing. Importantly, the ability of CBD to inhibit mesolimbic DAergic activity and blunt fearrelated memory formation is particularly intriguing given the large body of evidence demonstrating that the primary psychoactive phytochemical in cannabis, THC, produces propsychotic effects (Kuepper et al, 2011). Furthermore, in direct contrast to the effects of CBD, THC has been shown to induce a state of hyperactive mesolimbic DAergic activity following adolescent neurodevelopmental exposure (Renard et al, 2016a). In addition, we have recently reported that intra-NASh CBD blocks hyper-DAergic activity and psychomotor sensitization induced by amphetamine exposure (Renard et al, 2016b).

Several clinical and preclinical reports have suggested that $\mathrm{CBD}$ can reduce anxiety and may serve to ameliorate symptoms associated with emotional memory disorders such as PTSD. For example, CBD has been reported to facilitate the extinction of previously acquired traumatic or associative fear memories (Bitencourt et al, 2008; Stern et al, 2012; Das et al, 2013). While currently no clinical evidence has reported specific long-term therapeutic effects of CBD in PTSD patient populations, PTSD has been associated with dysregulation of $5-\mathrm{HT}_{1 \mathrm{~A}}$ expression levels in brain regions responsible for emotional memory and processing, such as the amygdala (Sullivan et al, 2013). Furthermore, preclinical evidence has shown also that genetic deletion of the $5-\mathrm{HT}_{1 \mathrm{~A}}$ receptor in mice leads to potentiated reactivity to fear-related conditioning cues (Klemenhagen et al, 2006). Future research is required to more precisely characterize the mechanisms by which $\mathrm{CBD}$ and $5-\mathrm{HT}_{1 \mathrm{~A}}$ receptor substrates 
may interact and how these processes may, in turn, regulate emotional memory formation.

In summary, the present study reveals several novel insights regarding the functional effects of $\mathrm{CBD}$ on emotional memory processing and identifies a $5-\mathrm{HT}_{1 \mathrm{~A}}$ receptor mechanism within the NASh as an underlying mechanism by which CBD may regulate mesolimbic activity and modulate the formation of associative emotional memories. Furthermore, these findings underscore growing evidence demonstrating that differential phytochemical constituents of cannabis (CBD vs THC) can produce divergent and opposing effects on DAergic activity states and emotional memory behaviors.

\section{FUNDING AND DISCLOSURE}

The authors declare no conflict of interest.

\section{ACKNOWLEDGMENTS}

Funding for this research provided by the Canadian Institutes of Health Research (MOP-246144) and the Natural Science and Engineering Council of Canada. The authors declare that they have no competing financial interests with the research reported.

\section{REFERENCES}

Betthauser K, Pilz J, Vollmer LE (2015). Use and effects of cannabinoids in military veterans with posttraumatic stress disorder. Am J Health Syst Pharm 72: 1279-1284.

Bhattacharyya S, Crippa JA, Allen P, Martin-Santos R, Borgwardt S, Fusar-Poli $\mathrm{P}$ et al (2012). Induction of pychosis by 9-tetrahydrocannabinol reflects modulation of prefrontal and striatal function during attentional salience processing. Arch Gen Psychiatry 69: 27-36.

Bhattacharyya S, Fusar-Poli P, Borgwardt S, Martin-Santos R, Nosarti C, O'Carrol C et al (2009). Modulation of mediotemporal and ventrostriatal function in humans by $\Delta^{9}$-tetrahydrocannabinol. Arch Gen Psychiatry 66: 442-451.

Bisogno T, Hanus L, De Petrocellis L, Tchilibon S, Ponde DE, Brandi I et al (2001). Molecular targets for cannabidiol and its synthetic analogues: effect on vanilloid VR1 receptors and on the cellular uptake and enzymatic hydrolysis of anandamide. $\mathrm{Br} \mathrm{J}$ Pharmacol 134: 845-852.

Bitencourt RM, Pamplona FA, Takahashi RN (2008). Facilitation of contextual fear memory extinction and anti-anxiogenic effects of AM404 and cannabidiol in conditioned rats. Eur Neuropsychopharmacol 18: 849-859.

Blessing EM, Steenkamp MM, Manzanares J, Marmar CR (2015). Cannabidiol as a potential treatment for anxiety disorders. Neurotherapeutics 12: 825-836.

Campos AC, Ferreira FR, Guimarães FS (2012). Cannabidiol blocks long-lasting behavioral consequences of predator threat stress: possible involvement of $5 \mathrm{HT}_{1 \mathrm{~A}}$ receptors. J Psychiatr Res 46: 1501-1510.

Crippa JAS, Derenusson GN, Ferrari TB, Wichert-Ana L, Duran FL, Martin-Santos R et al (2011). Neural basis of anxiolytic effects of cannabidiol (CBD) in generalized social anxiety disorder: a preliminary report. J Psychopharmacol 25: 121-130.

Das RK, Kamboj SK, Ramadas M, Yogan K, Gupta V, Redman E et al (2013). Cannabidiol enhances consolidation of explicit fear extinction in humans. Psychopharmacology 226: 781-792.
Draycott B, Loureiro M, Ahmad T, Tan H, Zunder J, Laviolette SR (2014). Cannabinoid transmission in the prefrontal cortex bi-phasically controls emotional memory formation via functional interactions with the ventral tegmental area. J Neurosci 34: 13096-13109.

ElSohly MA, Slade D (2005). Chemical constituents of marijuana: the complex mixture of natural cannabinoids. Life Sci 78: 539-548.

Fogaca MV, Reis FM, Campos AC, Guimarães FS (2014). Effects of intra-prelimbic prefrontal cortex injection of cannabidiol on anxiety-like behavior: involvement of $5 \mathrm{HT}_{1 \mathrm{~A}}$ receptors and previous stressful experience. Eur Neuropsychopharmacol 24: 410-419.

Fujita S, Kiguchi M, Lee J, Terakado M, Suga K, Hatanaka $\mathrm{H}$ et al (2008). 5-HT $1 \mathrm{~A}$ and 5-HT $1 \mathrm{~B}$ receptors in the ventrolateral striatum differentially modulate apomorphine-induced jaw movements in rats. J Oral Sci 50: 387-395.

French ED, Dillon K, Wu X (1997). Cannabinoids excite dopamine neurons in the ventral tegmentum and substantia nigra. Neuroreport 8: 649-652.

Gomes FV, Llorente R, Del Bel EA, Viveros M-P, López-Gallardo M, Guimarães FS (2015). Decreased glial reactivity could be involved in the antipsychotic-like effect of cannabidiol. Schizophr Res 164: $155-163$.

Guimarães V, Zuardi AW, Del Bel EA, Guimarães FS (2004). Cannabidiol increases Fos expression in the nucleus accumbens but not in the dorsal striatum. Life Sci 75: 633-638.

Ichikawa J, Kuroki T, Kitchen MT, Meltzer HY (1995). R(+)-8-OHDPAT, a 5-HT1A receptor agonist, inhibits amphetamineinduced dopamine release in rat striatum and nucleus accumbens. Eur J Pharmacol 287: 179-184.

Jalabert M, Bourdy R, Courtin J, Veinante P, Manzoni OJ, Barrot M et al (2011). Neuronal circuits underlying acute morphine action on dopamine neurons. Proc Natl Acad Sci USA 108: 16446-16450.

Johnson EA, Tsai CE, Shahan YH, Azzaro AJ (1993). Serotonin 5HT1A receptors mediate inhibition of tyrosine hydroxylation in rat striatum. J Pharmacol Exp Ther 266: 133-141.

Kalivas PW, Churchill L, Klitenick MA (1993). GABA and enkephalin projection from the nucleus accumbens and ventral pallidum to the ventral tegmental area. Neuroscience 57: 1047-1060.

Katsidoni V, Anagnostou I, Panagis G (2013). Cannabidiol inhibits the reward-facilitating effect of morphine: involvement of $5-\mathrm{HT}_{1 \mathrm{~A}}$ receptors in the dorsal raphe nucleus. Addict Biol 18: 286-296.

Klemenhagen KC, Gordon JA, David DJ, Hen R, Gross CT (2006). Increased fear response to contextual cues in mice lacking the 5- $\mathrm{HT}_{1 \mathrm{~A}}$ receptor. Neuropsychopharmacology 31: 101-111.

Kuepper R, van Os J, Lieb R, Wittchen H-U, Höfler M, Henquet C (2011). Continued cannabis use and risk of incidence and persistence of psychotic symptoms: 10 year follow-up cohort study. BMJ 342: 1-9.

Lauzon NM, Bishop SF, Laviolette SR (2009). Dopamine D1 versus D4 receptors differentially modulate the encoding of salient versus nonsalient emotional information in the medial prefrontal cortex. J Neurosci 29: 4836-4845.

Leweke FM, Piomelli D, Pahlisch F, Muhl D, Gerth CW, Hoyer C et al (2012). Cannabidiol enhances anandamide signaling and alleviates psychotic symptoms of schizophrenia. Transl Psychiatry 2: e94.

Loureiro M, Renard J, Zunder J, Laviolette SR (2015). Hippocampal cannabinoid transmission modulates dopamine neuron activity: impact on rewarding memory formation and social interaction. Neuropsychopharmacology 40: 1436-1447.

Marinho AL, Vila-Verde C, Fogaça MV, Guimarães FS (2015). Effects of intra-infralimbic prefrontal cortex injections of cannabidiol in the modulation of emotional behaviors in rats: contribution of $5 \mathrm{HT}_{1}$ A receptors and stressful experiences. Behav Brain Res 286: 49-56. 
McPartland JM, Duncan M, Di Marzo V, Pertwee RG (2015). Are cannabidiol and $\Delta(9)$-tetrahydrocannabivarin negative modulators of the endocannabinoid system? A systematic review. Br J Pharmacol 172: 737-753.

Mechoulam R, Peters M, Murillo-Rodriguez E, Hanuš LO (2007). Cannabidiol-recent advances. Chem Biodivers 4: 1678-1692.

Mijangos-Moreno S, Poot-Aké A, Arankowsky-Sandoval G, Murillo-Rodríguez E (2014). Intrahypothalamic injection of cannabidiol increases the extracellular levels of adenosine in nucleus accumbens in rats. Neurosci Res 84: 60-63.

Murillo-Rodríguez E, Millán-Aldaco D, Palomero-Rivero $\mathrm{M}$, Mechoulam R, Drucker-Colín R (2006). Cannabidiol, a constituent of Cannabis sativa, modulates sleep in rats. FEBS Lett 580: 4337-4345.

Murray RM, Morrison PD, Henquet C, Di Forti M (2007). Cannabis, the mind and society: the hash realities. Nat Rev Neurosci 8: 885-895.

Nauta WJ, Smith GP, Faull RL, Domesick VB (1978). Efferent connections and nigral afferents of the nucleus accumbens septi in the rat. Neuroscience 3: 385-401.

Paxinos G, Watson C. The Rat Brain in Stereotaxic Coordinates, 6th edn. Elsevier: San Diego, CA, USA, 2005.

Pedrazzi JFC, Issy AC, Gomes FV, Guimarães FS, Del-Bel EA (2015). Cannabidiol effects in the prepulse inhibition disruption induced by amphetamine. Psychopharmacology (Berl) 232: 3057-3065.

Pertwee RG (2008). The diverse CB1 and CB2 receptor pharmacology of three plant cannabinoids: delta9-tetrahydrocannabinol, cannabidiol and delta9-tetrahydrocannabivarin. $\mathrm{Br} J$ Pharmacol 153: 199-215.

Radwan MM, ElSohly MA, Slade D, Ahmed SA, Khan IA, Ross SA (2009). Biologically active cannabinoids from high-potency Cannabis sativa. J Nat Prod 72: 906-911.

Renard J, Rosen LG, Loueiro M, De Oliveira C, Schmid S, Rushlow WJ et al (2016a). Adolescent cannabinoid exposure induces a persistent sub-cortical hyper-dopaminergic state and associated molecular adaptations in the prefrontal cortex. Cereb Cortex (e-pub ahead of print 4 January 2016).

Renard J, Rosen LG, Loueiro M, Zunder J, De Oliveira C, Schmid S et al (2016b). Cannabidiol counteracts amphetamine-induced neuronal and behavioral sensitization of the mesolimbic dopamine pathway through a novel mTOR/p70S6 kinase signaling pathway. J Neurosci (e-pub ahead of print 4 May 2016).
Rosen LG, Zunder J, Renard J, Fu J, Rushlow W, Laviolette SR (2015). Opiate exposure state controls a D2-CaMKII $\alpha$-dependent memory switch in the amygdala-prefrontal cortical circuit. Neuropsychopharmacology 41: 847-857.

Russo EB, Burnett A, Hall B, Parker KK (2005). Agonistic properties of cannabidiol at $5-\mathrm{HT}_{1 \mathrm{a}}$ receptors. Neurochem Res 30: 1037-1043.

Schubart CD, Sommer IEC, Fusar-Poli P, de Witte L, Kahn RS, Boks MPM (2014). Cannabidiol as a potential treatment for psychosis. Eur Neuropsychopharmacol 24: 51-64.

Stern CAJ, Gazarini L, Takahashi RN, Guimarães FS, Bertoglio LJ (2012). On disruption of fear memory by reconsolidation blockade: evidence from cannabidiol treatment. Neuropsychopharmacology 37: 2132-2142.

Sullivan GM, Ogden RT, Huang YY, Oquendo MA, Mann JJ, Parsey RV (2013). Higher in vivo serotonin-1A binding in posttraumatic stress disorder: a PET study with $\left[{ }^{11} \mathrm{C}\right]$ WAY-100635. Depress Anxiety 30: 197-206.

Tan H, Bishop SF, Lauzon NM, Sun N, Laviolette SR (2009). Chronic nicotine exposure switches the functional role of mesolimbic dopamine transmission in the processing of nicotine's rewarding and aversive effects. Neuropharmacology 56: 741-751.

Thomas A, Baillie GL, Phillips AM, Razdan RK, Ross RA, Pertwee RG (2007). Cannabidiol displays unexpectedly high potency as an antagonist of $\mathrm{CB} 1$ and $\mathrm{CB} 2$ receptor agonists in vitro. Br J Pharmacol 150: 613-623.

Thomas BF, Gilliam AF, Burch DF, Roche MJ, Seltzman HH (1998). Comparative receptor binding analyses of cannabinoid agonists and antagonists. J Pharmacol Exp Ther 285: 285-292.

Ungless MA, Ungless MA, Magill PJ, Bolam JP (2004). Uniform Inhibition of dopamine neurons in the ventral tegmental area by aversive stimuli. Science 303: 2040-2042.

Valvassori SS, Elias G, de Souza B, Petronilho F, Dal-Pizzol F, Kapczinski F (2011). Effects of cannabidiol on amphetamineinduced oxidative stress generation in an rat model of mania. J Psychopharmacol 25: 274-280.

Zuardi AW, Crippa JAS, Hallak JEC, Bhattacharyya S, Atakan Z, Martin-Santos $\mathrm{R}$ et al (2012). A critical review of the antipsychotic effects of cannabidiol: 30 years of a translational investigation. Curr Pharm Des 18: 5131-5140.

Zuardi AW, Crippa JAS, Hallak JEC, Moreira FA, Guimaraes FS (2006). Cannabidiol, a Cannabis sativa constituent, as an antipsychotic drug. Brazil J Med Biol Res 39: 421-429. 